Article

\title{
An insight on B2B Firms in the Age of Digitalization and Paperless Processes
}

\author{
José Oliveira $^{1}\left(\right.$, António Azevedo ${ }^{2}\left(\mathbb{D}\right.$, João J. Ferreira ${ }^{3}\left(\mathbb{C}\right.$, Sofia Gomes ${ }^{4}\left(\mathbb{D}\right.$ and João M. Lopes ${ }^{5, *(1)}$ \\ 1 Instituto Superior Politécnico Gaya (ISPGAYA), 4400-103 Vila Nova de Gaia, Portugal; \\ jcastroliveira@ispgaya.pt \\ 2 School of Economics and Management, University of Minho, 4710-057 Braga, Portugal; \\ antonioa@eeg.uminho.pt \\ 3 Department of Management and Economics \& NECE—Research Unit in Business Sciences, \\ University of Beira Interior, 6201-001 Covilhã, Portugal; jjmf@ubi.pt \\ 4 REMIT-Research on Economics, Management and Information Technologies, University Portucalense, \\ 4200-072 Porto, Portugal; sofiag@upt.pt \\ 5 Miguel Torga Institute of Higher Education \& University of Beira Interior \& NECE-Research Unit in \\ Business Sciences, 6201-001 Covilhã, Portugal \\ * Correspondence: joao.lopes.1987@hotmail.com
}

Citation: Oliveira, J.; Azevedo, A.; Ferreira, J.J.; Gomes, S.; Lopes, J.M. An insight on B2B Firms in the Age of Digitalization and Paperless Processes. Sustainability 2021, 13, 11565. https://doi.org/10.3390/ su132111565

Academic Editors: Alan Randall and Oscar F. Bustinza

Received: 23 July 2021

Accepted: 16 September 2021

Published: 20 October 2021

Publisher's Note: MDPI stays neutral with regard to jurisdictional claims in published maps and institutional affiliations.

Copyright: (c) 2021 by the authors. Licensee MDPI, Basel, Switzerland. This article is an open access article distributed under the terms and conditions of the Creative Commons Attribution (CC BY) license (https:// creativecommons.org/licenses/by/ $4.0 /)$.

\begin{abstract}
In recent years and due to market demand and environmental regulations, firms have been changing their procedures regarding document production, handling, and filling. There has been a paradigm change in document sustention in order to attain such changes, from paper-based to electronic forms, resulting in the Digitization and Paperless Office Program (DPOP). The literature on digitization and paperless processes is profuse; nonetheless, it is outdated, uses only single or multiple case study approaches, and is limited to specific industries, such as healthcare or higher education. To overcome this gap, this research analyses the current implementation of the DPOP in five major sectors by using a country scale approach; consequently, this research study contributes to strengthening the literature in this area of knowledge. The methodology used is quantitative and is based on a questionnaire distributed to the most important economic sectors (education, health, trade, industry, and services) in Portugal. The results show that a DPOP positively impacts companies, as it increases profitability and, in most cases, is a sine qua non condition for negotiating with clients. Additionally, it favours companies' image, reduces costs, and contributes to environmental sustainability. This research provides new insights into how firms using a DPOP may contribute to dematerialization and paper consumption reduction. It is also original as it covers multiple sectors using a country approach.
\end{abstract}

Keywords: digitization; paperless office; paper reduction; dematerialization; office printing industry; corporate image; servitization; downsizing; business-to-business services

\section{Introduction}

At present, there is an increasing concern that the demand for energy and raw materials will overcome the existing resources of the planet. What can be done to assure the future of the next generations? The environmental consequences of the continued economic growth resulted in intense academic and political debates, calling for a transition to a "green economy" and a complete change in the paradigm of growth and development, which resulted in the notions of orientation to sustainability [1,2] and dematerialization. Some authors use the notion of dematerialization as a synonym for digitization $[2,3]$, service innovation [1,4], organizational technology [5], or servitization/deservitization [6,7].

Since dematerialization may take many forms, in this paper, the term will be used as a synonym for the reduction in paper consumption and to refer to the consequences of the digitization of information and the implementation of paperless policies in organizations 
and firms, which is referred to as a Digitization and Paperless Office Program (DPOP) here. What is the relevance of studying the phenomenon of the paperless office movement? What new lessons can we learn from this endeavour? Moreover, what is the contribution of this paper to the field of knowledge? These questions will be answered in this section.

There are a limited number of studies about the research topic of "paperless movement"; the authors of [8] found only 15 papers and stressed that "the relevant articles were published in the year 2000". The articles that are deemed relevant are either (a) too old, (b) focused on the medical industry [9], or (c) use a single or multiple case study approach [3,9]. According to our knowledge, no studies have analysed this problem using a country scale approach. This paper aims to discuss dematerialization through the implementation of a DPOP and its consequences both for the firms under study and, ultimately, for the suppliers of office printing products and services. Therefore, it addresses a gap in the literature because it proposes a holistic theoretical framework, acknowledging the consequences of digitization and paperless offices in the last stage of the printing supply chain-the business-to-business (B2B) customer. Moreover, this paper also contributes by providing knowledge to this field, as it aims to reveal new justifications for the increment of paper production worldwide (Jevons Paradox).

From a sustainability perspective, wood pulp and paper industries have stabilized their extraction rate of new materials $[10,11]$. Bais et al. [12] investigated the trends of wood harvesting and use in 2010 and verified that, from the Total Biomass Appropriation (TBA) of 1936 thousand tonnes of carbon (MtC)/year extracted, 273 thousand tonnes $\mathrm{MtC}$ /year was used to produced paper, while 169 thousand tonnes $\mathrm{MtC} /$ year was recycled. Recovered fibre pulp from recovered paper is assumed to be utilized for $62 \%$ of paper and paperboard product production.

However, environmentalists claim that one tonne of uncoated virgin (non-recycled) printing and office paper uses 24 trees. Therefore, the pressure to reduce wood pulp exploration impels organizations to reduce paper consumption and to communicate this social responsibility endeavour to their stakeholders in order to improve their environmental reputation.

Many organizations and firms engaged in paperless and digitalization programs are persuaded to do so by environmental arguments, such as eco-labelling certification schemes [8,13], and, largely, factors related to cost reduction, environmental aspects, document size, archiving, retrieval, and others. Therefore, it is imperative to investigate how the business-to-business (B2B) customers in different sectors cope with dematerialization, particularly regarding the paperless movement. What endogenous drivers affect the strategic decisions, needs, and demand for office printing products and services? This diagnostic will be an important strategic input for the office printing manufacturer industry. The different sectors will be discussed later for the formulation of Hypothesis H1.

The authors selected Portugal for a convenience case study analysis. According to the 2016 FAO statistics, Portugal is the eighth highest world producer of wood pulp for paper (1515 million tonnes), and it belongs to the group of "worst" countries that had higher material usage rates according to Pothen and Schymura [10]. This paper aims to analyse the B2B market in the most important economic sectors (trade, health, education, industry, and services) and the public administration sector.

According to Yoo et al. [14], Hylving and Schultze [15], and Sotnyk et al. [16], the new architecture of information systems, resulting from digital innovation, instigates profound changes in the ways that firms plan for innovation in the future. Internal factors will be discussed later for the formulation of Hypotheses $\mathrm{H} 2 \mathrm{a}$ and $\mathrm{H} 2 \mathrm{~b}$.

The number of emerging studies focusing on the office printing sector also demonstrates that this industry is one of the most affected industries with respect to digitization and paper dematerialization. Therefore, a diagnostic of the paperless movement will provide interesting insights for the managers of office printing manufacturers. The outcome and consequences of office dematerialization will later be used to formulate Hypotheses $\mathrm{H} 3$ and $\mathrm{H} 5$. 
In the present study, we used a quantitative methodology and used the KolmogorovSmirnov and Shapiro-Wilk tests, nonparametric techniques, and, thus, the Kruskal-Wallis test. The questionnaire was distributed to a sample of 725 companies in Portugal, covering five sectors (education, health, commerce, industry, and services) to which 151 valid responses were received.

The results show that DPOP has a positive impact as it increases the profitability of companies and, in most cases, is a sine qua non condition to negotiate with clients. Moreover, it favours the image of companies, reduces costs, and is seen as an important contributor to environmental and sustainability reputation. This article provides new insights on how firms under DPOP may contribute to dematerialization and paper consumption reduction. This research is original as it covers five major sectors using a country scale approach. Other relevant studies on the paperless movement are outdated and use only single or multiple case study approach in specific industries such as healthcare or higher education. Although the obtained results measure real trends and behaviours towards DPOP, they do not express any metrics associated with DPOP. As this is a new area amongst B2B companies, there are no KPIs associated with this area. KPIs (Key Performance Indicators) are a very strong mean to compare and benchmark results within similar families of measures for businesses or processes, but they may fail if they do not consider the difference in goals and business processes [17]. The infrequent studies focused on KPIs' availability are normally focused on research problems concerning KPIs but not necessarily related to the factors that influence the organization disclosure. Therefore, the availability of KPIs and the standardisation of KPIs are important for ensuring their relevance and applicability [18]. This being the case, in creating KPIs and ensuring their usefulness, "Companies are expected to report KPIs that are useful taking into account their specific circumstances. The KPIs should be consistent with metrics actually used by the company in its internal management and risk assessment processes" [19].

This paper is organized as follows: It starts with an introduction to the problem under study. In Section 2, a literature review discusses the drivers of dematerialization, focusing on the orientation for sustainability and the engagement in a DPOP process. Section 3 analyses methodology and data collection. Section 4 is focused on the discussion of results supported by the relevant literature. Finally, the last part presents the main conclusions, contributions to literature and practice, and research limitations and clues for future investigations.

\section{Literature Review}

\subsection{From Dematerialization to Digitization and Paperless Firms' Movement}

Currently, digitization and paperless movement are holistic topics amongst modern societies, and these are grounded by several reasons related to environmental motives, cost reduction, new technology, or even corporate image. Several authors point to two exogenous market drivers that are pushing the paperless movement: (1) the orientation for sustainability [1,2,20]; and (2) the digitization of information as a consequence of information and communication technology (ICT) revolution [14,21-24], creating opportunities to diffuse digital documents throughout networks [25].

For Tronvoll, Sklyar, Sorhammar, and Kowalkowski [4], dematerialization is related to the growing importance of data and information (as opposed to physical products such as paper and printing equipment); on the other hand, Malenbaum [26] and Bernardini and Galli [27] describe dematerialization "as the reduction in the quantity of stuff and or energy needed to produce something useful and is then often assessed by a measure of the intensity of use or throughput (consumption/production of energy and/or goods per GDP)" (Magee and Devezas, p. 196). This ratio of DMC/GDP (Domestic Material Consumption/ Gross Domestic Product) is also designated as resource or material intensity. Schandl et al. [28] and Lawson et al. [29] affirmed that dematerialization is possible with well-designed policy settings and would not contradict the efforts to raise human well- 
being and living standards. OECD economies have significant potentials to reduce their material throughput and carbon emissions with little impact on economic growth.

According to some Material Flow Analysis (MFA) studies, the amount of biomass (including wood pulp) extracted is stable. Pothen and Schymura [10] concluded that the amount of materials used worldwide in production and consumption increased by $56 \%$ from 1995 to 2008. By using index decomposition analysis (IDA), these authors investigated the drivers of material used in a panel dataset of 40 countries, accounting for $75 \%$ of worldwide material extraction and $88 \%$ of GDP. They used the World Input-Output Database (WIOD) (described by [30-32] and available at http://www.wiod.org/home (accessed on 22 September 2020)) containing harmonized input-output tables and data on material extraction for the 40 major economies and 34 sectors. Two conclusions emerged: (1) in the period 1995-2008, the average rate of growth of extracted material of pulp, paper, paper products, printing, and publishing (NACE Code 21t22) is about $2 \%$; (2) Portugal belongs to the "worst" countries group because its rate of extraction is one of greatest among the 40 countries. According to CELPA [33], this is aggravated due to pulp paper production's strategic nature of the Portuguese economy. In 2008, the total sales of paper pulp was circa 900 Ktonnes, and this figure increased to 1300 Ktonnes by 2016. From the total production, approximately $5 \%$ is for domestic consumption, and the remaining is for export.

Still, Ayres and van den Bergh [6], Magee and Devezas [34], and Tronvoll, Sklyar, Sorhammar and Kowalkowski [4] claim that dematerialization has an implicit growth mechanism that can be counteracted by a demand rebound, which increases usage due to increased value (or decreased cost); this also results from increasing technical performance and innovation [20]. This rebound is also known as the Jevons Paradox. By 1865, this author warned that gains in the use of any resource tend to be followed by increases rather than decreases in consumption $[35,36]$.

York [37] identified this paradox in the paper industry as there was an increase in paper consumption after moving to "paperless offices". Against all probabilities and the logical consequence of dematerialization, office paper demand (technically named as cut size free sheet) did not suffer a reduction; instead, a rebound effect occurred, and the trend is an increase in the demand until 2023 [38]. By examining the demand by global areas, we can observe a decay in Europe and USA and a steady demand in the Oceania but increasing demand in the rest of the world.

The preliminary statistics of the Confederation of European Paper Industries (CEPIwww.cepi.org; accessed on 24 February 2020) show an increase in paper and board production from 80 million tonnes in 1996 to 91 million in 2016. The world paper and board production grew up to $0.8 \%$ in 2016, reaching 410 million tonnes. Gnoni and Elia [13] suggested a conceptual framework of the printing supply chain (see Figure 1) that exhibits a broad view of paper flows and the related consumptions of energy and materials. According to CEPI [39], from 1991 to 2020, paper and board production increased by $0.9 \%$. For the same period, the consumption of these commodities was augmented by $0.6 \%$.

This paper is focused on the last stage of this supply chain-the B2B customer. The next section will discuss all the consequences of digitization and paperless in B2B offices. 


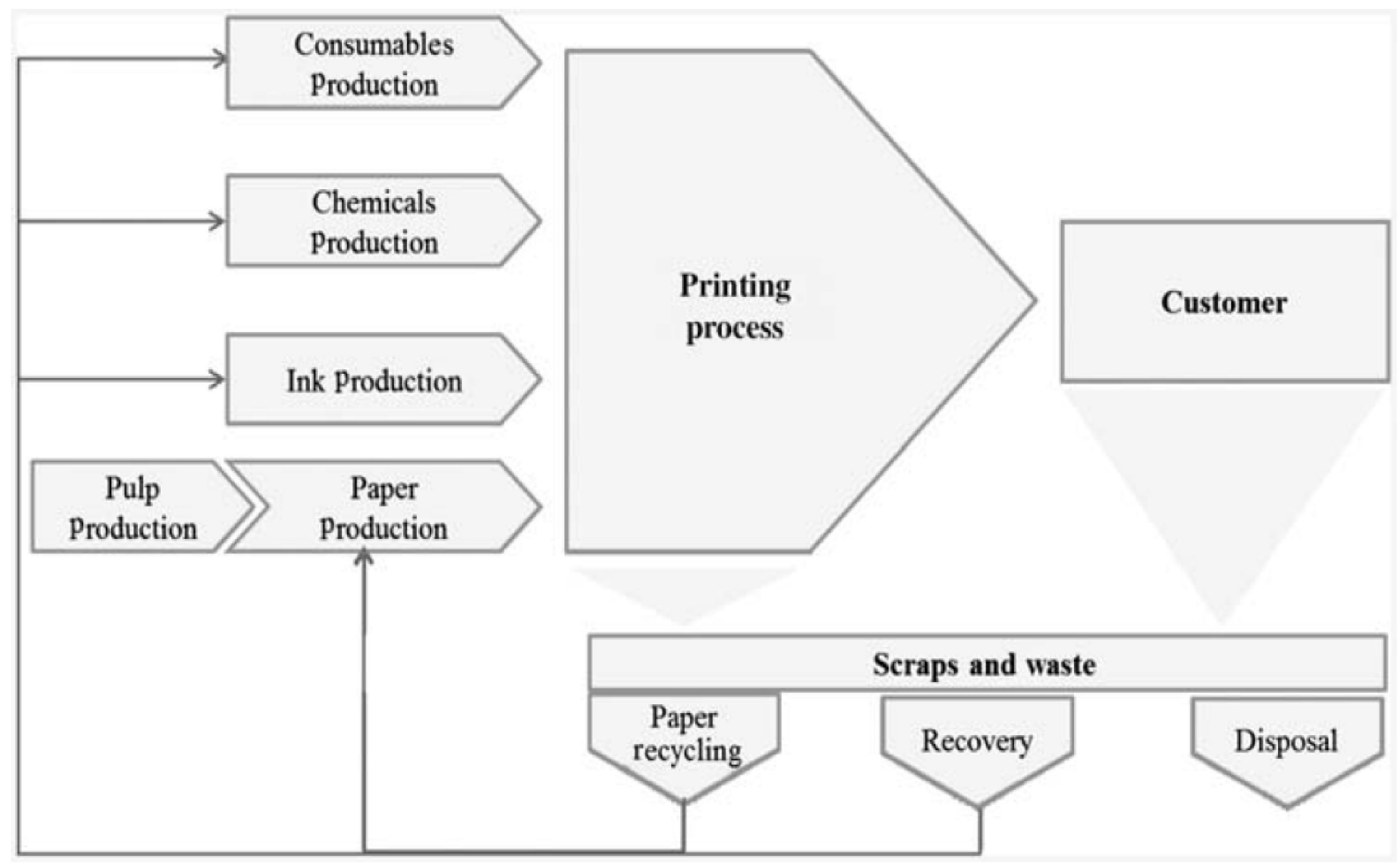

Figure 1. Main process stages in the printing supply chain. Source: Gnoni and Elia [13].

\subsection{Digitization from Inside the Organizations: Benefits and Barriers}

Greenwood [40] and Chao [8] pointed out several reasons that diminished paper usage in documents versus the new paperless type: (1) Paper must be used on-site and cannot be accessed from a distance; (2) being a physical support, paper occupies space, and this can be a problem for archiving and storage; (3) in order to be delivered, paper documents require external actions (i.e., post); (4) a paper document can only be used by one reader at a time; (5) due to the definitive displacement of the information on top of the paper, paper documents cannot be easily revised, reformatted, and merged with other documents; (6) in order to replicate a paper document, external technology is needed (i.e., photocopiers, scanners, etc.); (7) paper documents can only retain static information (wording or images); and (8) paper-based systems are less safe because they are exposed to several risks of destruction.

On the other hand, digital records are vulnerable to cybernetic attacks (Cumming and Findlay [41]). In order to be used for legal and other business purposes, digital records need to be meaningful and trustworthy [42]. Furthermore, according to Jones [43], corporate electronic document management systems (EDMS) have several benefits: (a) customer service representatives have access to the information needed to provide complete service; (b) staff can access the information needed to perform their duties anywhere; (c) the creation of electronic documents means that paper originals can be destroyed, reducing filing space; (e) reduction in printing and printers due to electronic documents; (f) reduction in staff due to improved efficiency; (g) the provision of an audit trail of electronic information updates; and $(\mathrm{h})$ the improvement of information management.

Although it is notorious that a transition to dematerialization is occurring in today's offices, there is no clear evidence that establishes that it occurs in all offices and at similar levels [44]. Other studies revealed that despite the widespread use of digital technologies, paper and material artefacts remain pervasive and critical resources in accomplishing workplace activities underpinning communication and collaboration [45].

When comparing the human brain's reaction between a paper document and a digital document (viewed on a screen), the attitude is remarkably different. For a paper document, 
our brain looks to a passive light source (reflective), whereby four of the five senses are used. Our eyes will read and easily scroll the document. By touching and feeling the document (loose pages or book), the brain perceives the deepness of the document, age, and type of subtract. Furthermore, the smell and sound of paper defoliating will add additional information on the physical characteristics of the document. On the other hand, when viewing a digital document through a screen, our brain always looks to an active light source, adjusting only one sense-our vision-accordingly. Studies in the past two decades indicate that people often understand and remember text on paper better than on a screen [46]. Screens may inhibit comprehension by preventing people from intuitively navigating and mentally mapping long texts.

\subsection{Consequences of Digitation and Paperless Office Programs to Firms' Business Models}

According to Coreynen, Matthyssens, and Van Bockhaven [3], digitation can result in three servitization pathways (industrial, commercial, and value). Servitization, the terminology advanced by Vandermerwe and Rada [47] and later by Brax and Visintin [48], characterizes the transition from a production base to introducing integrated solutions and new services. Servitization is now widely recognized as the innovation of a manufacturer's capabilities and processes to move from selling products to selling integrated products-service offerings that deliver value in use [49-52]. Nonetheless, servitization is still a complex process, and the connection between the implementation of services and companies' performance is still fuzzy [53].

For the manufacturing firms pretending to servitize, some barriers were identified [54]: (1) firms are not adequately able to recognize the economic potential of the service component; (2) providing services is beyond the scope of their competencies; and (3) firms fail to successfully deploy a service strategy during the transitioning into services phase. Furthermore, physical products no longer guarantee competitive advantage, financial performance, and market opportunities [54]. As a result, manufacturers increasingly seek new value in services and integrated solutions from their traditional business models based on product sales [55]. To secure the benefits from services, manufacturing companies find themselves in a challenging capability and organizational transformation [25].

\subsection{Impact of Dematerialization on Office Printing Industry: Concentration and Servitization}

The evolution of paper usage as a physical support for documents has five significant momentums (see Figure 2): (1) document materialization; (2) dissemination through organizations; (3) technological breakthrough; (4) commoditization; and (5) dematerialization. Of the five momentums, it is possible to denote specific milestones characterizing each period. The materialization started with the invention of paper in China in the 2nd century but with limited usage. By the 15th century, with the invention of the press in Germany by Guttenberg, printed documents significantly increased. New inventions, such as the typewriter, duplicators, and copiers by the 19th century, allowed organizations to produce and reproduce documents in-house and easily. The 20th century witnessed new revolutionary technologies that allowed the introduction of the matrix printer, the photocopier, the inkjet and laser printer, and the advent of multi-function devices at a later stage, which allowed the aggregation of several functions such as fax, scanner, printer, and copier in one device. Nonetheless, the availability was scarce and limited to wealthier companies. With the evolution of technologies and globalization, by the beginning of the 21st century, these types of products became commodities and were available at affordable prices. Its massive use by companies led the way to a substantial dematerialization of documents that is now replaced by email, scanning, and faxing; nonetheless, the paper-based document remained but with less usage in organizations (as opposed to personal usage). 


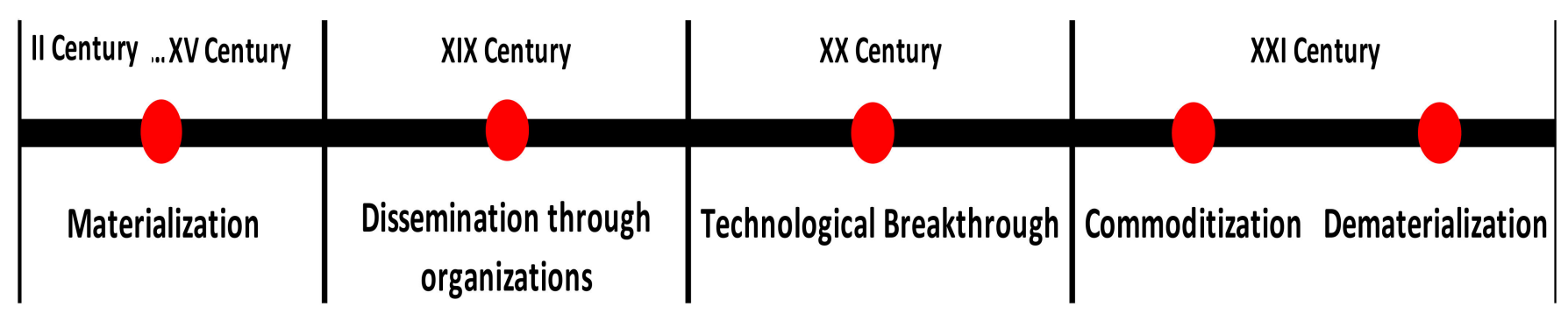

Figure 2. Timeline of paper usage for documents.

We have observed constant market changes that have been reflected in the printing solutions industry [56]. On the offering side to the market, initially, the manufacturing industries started by selling photocopiers and then adding printers, which is later followed by fax and scanners. Upon technological evolution, multi-function products (MFP) emerged with functionalities such as copying, printing, scanning, and faxing performed by a single unit. According to Infosource [57], MFP manufacturers of the office printing industry (B2B) by 2015 were as follows: Brother, Canon, Epson, Konica, Minolta, Kyocera, Lexmark, Muratec, Oki, Panasonic, Pantum, Ricoh, Samsung, Sharp, Toshiba, and Xerox. Similarly to Brother and Samsung, some of these players also have a large manufacturing portions of printers and small MFP for the consumer market (B2C). In 2015, the fifteen manufacturers sold 1.491.681 MFP units for the B2C market in Europe. Analysis by market share reflects that the top five manufacturers (Ricoh, Kyocera, Canon, Konica Minolta, and Fuji-Xerox) sold $80,28 \%$ of the units corresponding to 1.197.496 MFP [57].

Between 2011 and 2015, sales in Europe rose by 13,9\%, which corresponds to an increase of 208.706 units [57]. The process of dematerialization in companies did not affect these manufacturers in the office printing industry. This rebound effect is also supported by the study of Werner [58], who claims that due to the reduction in ICT's cost, the amount of energy consumption per capita increased in the EU for the period 2001-2013 for individuals/households. Household energy consumption further corroborates this trend for the period between 2000 and 2018. According to Eurostat [59], for this period, the energy consumed by households in the EU was $605.719,326$ gigawatt-hour in the year 2000 against 705.517, 655 gigawatt-hour by 2018, which represents an increment of $16.5 \%$ in energy consumption. Although faced with the importance of this reality and the possibility of offsetting paper consumption results, this is not relevant for this research study since the type of equipment used on B2B market has mandatory energy-saving modes, some of which are related to ISO norms and others are related to Energy Star.

\section{Hypothesis Development and Research Model}

The internal and external motivators for paperless dematerialization play an important role towards new sustainable patterns. In the literature, five types of motivators were identified:

(1) Economic issues: In Section 2.2, we understood that firms and organizations expect to gain economic benefits from the implementation of paperless offices, such as reduction in costs in paper and energy and increase in profitability due to gains in work efficiency $[9,60]$;

(2) Sustainability and Environmental issues: Several authors highlight the need of orientation for sustainability and pointed out the importance of evidence connecting the perception of dematerialization and the environment-related valuation of products and services; others stressed more specific motivations, for example, Chowdhury [61] argued that current printing and photocopying activities are not environmentally sustainable;

(3) Reduction in filling space: A considerable number of today's offices are concerned with the price of archive space. Since the square meter is more expensive than the Byte, a new method of thinking about office space has started to emerge [62,63]; 
(4) Imposing new processes/legal issues: The transition may encounter problems from the managerial point of view [64]. Windahl and Lakemond [65] stressed the importance of network management to develop integrated solutions. Such change requires the organization's capacity, competence, and solid architecture to integrate products and services. Today, immaterial-supported information constitutes a grey area, and most companies want to start the dematerialization process as legislation is unclear. Nonetheless, organizations are confronted with the legal necessity of paper-supported information. Some of these changes may affect human resources management regarding efficiency and working conditions. Downsizing and consequently reductions in personnel costs are expected as well [9];

(5) Image and reputation issues: Gray and Balmer [66] advocated that corporate image is the mental picture of the company. Regarding the impact of paperless programs, it was necessary to consider some dependent measures in the theoretical framework;

(a) Reduction in paper usage: According to Gardenal [21], dematerialization "has an environmental value, represented by the reduction in paper usage (which could also be represented with "saved trees"), and a financial value, represented by the reduction in archiving costs";

(b) Reduction in costs of the External Supplies and Services (ESS) with paper [67];

(c) Reduction in overall costs [63];

(d) Increase in profitability $[9,68]$;

(e) Corporate Image/Reputation: There several studies providing evidence from the adoption of paperless programs, mainly in the banking sector $[69,70]$;

(f) Investment in ICT (hardware/software) resulting directly from the implementation of the paperless office. Nevertheless, Jones [43] expects a decrease in the number of prints and printers;

(g) Reduction in the number of employees (downsizing) and/or personnel costs [9];

(h) The overall importance of dematerialization: Coroama et al. [71] warned about the potential environmental benefits expectations from electronic media with dematerialization and that care should be taken as electronic media may not be a straightforward solution for dematerialization; however, it can be facilitated it if its potential is actively used;

(i) Duration of the transition period: Velte, Velte, and Elsenpeter [67] and Stratton [72] reported that during the transition to paperless, the employee needs some adaption period as they often respond negatively, showing resistance to change.

Afterwards, it was necessary to identify all the relevant factors/independent variables that affect the dematerialization process. Although the impact of digitization was assessed only in few sectors such as health [9,73], Certified Public Accounts [63], or higher education $[43,74]$ or banking $[70,75]$, we think that the paperless office program implementation is influenced by the characteristics of the different business models of each activity sector. Based on the above assumptions, the following hypotheses were formulated.

Hypothesis 1. The type of economic activity sector influences the benefits and barriers from DPOP measured by indicators.

The firm dimension is usually defined by the number of employees or sales volume, and it is also an important independent variable, as claimed by Chao [8]. While technology supports the move to paperless business practices, not all organizations can afford the IT infrastructure necessary to transition and implement a service-oriented business strategy [3]. A small and medium-sized business (SMB) often lacks the resources and IT infrastructure to quickly increase server performance and/or expand storage capacity [76], both of which are required for the in-house computing infrastructure needed for effective digital storage and retrieval of documents [77]. 
Hypothesis 2a. Bigger firms (in terms of the number of employees) have a more favourable evaluation of the impact of paperless office programs.

Hypothesis $\mathbf{2} \mathbf{b}$. The sales volume is positively correlated with the indicator measuring the impact of paperless office programs.

The relative importance of the motivators for DPOP, discussed at the beginning of this section, may also influence the results, so a third hypothesis is developed.

Hypothesis 3. There is a positive correlation between the motivators and the indicators measuring the impact of the paperless office program.

We may also expect that if a firm perceives paper dematerialization with a higher degree of importance, this will trigger the reduction in paper consumption and decreases ESS costs while increasing profitability, thus positively impacting the firm's environmental reputation. This will lead us to the following hypothesis.

Hypothesis 4. There are positive correlations between the indicators measuring the impact of paperless office programs.

When dealing with radical processes implementation, time is the most vulnerable part of the equation in the plan and affects all related components. Therefore, the length of the process may influence the DPOP process and, consequently, its indicator because it is expected that visible results of DPOP may require a time delay in order to have impact on the indicators. This being so, we formulate the following hypothesis (Figure 3).

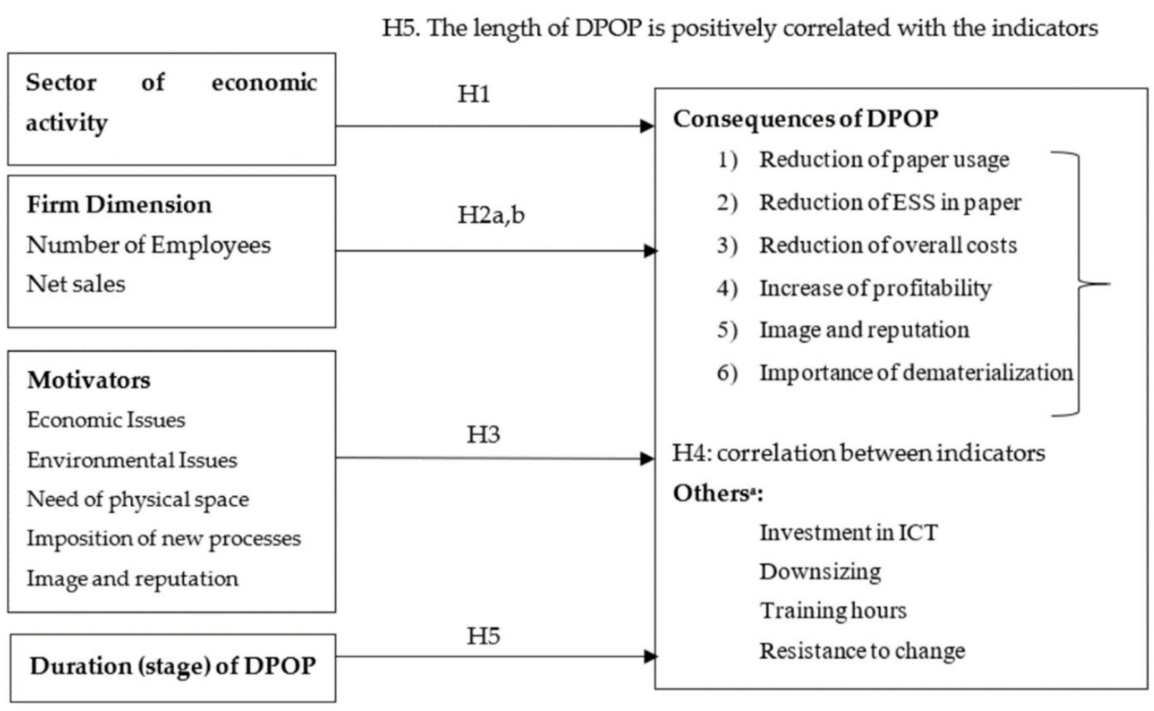

a Although these indicators were measured, they were not included in the hypothesis analysis for this paper.

Figure 3. Model describing the impact of DPOP on B2B customers.

\section{Methodology}

\subsection{Data Collection}

Informa D\&B (Dun \& Bradstreet) provided primary information about the universe of companies and institutions in Portugal (mainland) with net sales in 2014 equal to or greater than $10 \mathrm{M} €$. These chosen companies were the only ones that guaranteed the existence of the necessary data for this research study. The sample comprised 725 companies/institutions covering the following sectors: education, health, trade, undustry, and services.

By considering the feedback from three distinctive institutions in Portugal referenced as pioneers of dematerialization processes (Informa D\&B, Sonae group, and the University of Minho), a questionnaire was prepared. The questionnaire was validated, and a pre-test was performed for the first 25 responses, obtaining a Cronbach Alpha of 0.89 (reference 
value according to Hair, et al. [78] is 0.70). Finally, an email containing an introduction and a hyperlink to the questionnaire was sent to the universe of companies by using an online questionnaire between February and May of 2016. All received replies were anonymous and untraceable.

\subsection{Sample}

Recipients numbering 151 ( $21 \%$ of the universe) completed the questionnaire: trade (49), industry (41), services (28), health (15), and education (18). On the respondent function, finance directors and CEOs represented $83 \%$ of the sample. It was important to restrain the respondents to this type of function in order to avoid any bias in the responses, mainly due to diversity in response styles [53]. One of the information collected in the questionnaire was the approximate net sales of the companies in $2014(\mathrm{~K} €)$ (Mean $(\mathrm{M})=57,883.83$; Standard Deviation $(\mathrm{SD})=113,743.05$; Observations $(\mathrm{N})=129)$. Other information collected in this study included the number of employees of the companies $(\mathrm{M}=462.0$; $\mathrm{SD}=894.3 ; \mathrm{N}=150$ ). The respondent organizations have the following accreditations: ISO 9001-69.5\%; ISO 14001-17.9\%. Twenty-eight point five percent of the recipients $(\mathrm{N}=43)$ answered that they have no accreditation at all.

\section{Discussion of Results: Digitation and Paperless Office Program Impact Assessment}

The study by Vendrell-Herrero et al. [79] shows some similarities between document dematerialization and the publishing industry. In this study, the authors refer to the empirical context related to the availability of dematerialized books (eBook) and pointed out some motivations within this industry that offered dematerialized book contents: added value, profit-maximization, copyrights, and company image (modernity). In document dematerialization, there are similar motivations for dematerialization: economic issues, sustainability/environment issues, the need for physical (archive) space, and matters related to image or reputation.

\subsection{Motivation for Dematerialization}

The items selected to characterize motivation for dematerialization were as follows: economic issues, sustainability/environment issues, need of physical space, imposition of new processes, and matters related to image or reputation as used in the study of VendrellHerrero et al. [79]. Considering a Likert scale from 1 to 7 (1 being not important and 7 being very important), Table 1 illustrates how the need for physical space was the item with a higher mean, followed by economic issues and sustainability/environmental issues.

Table 1. Motivations for dematerialization.

\begin{tabular}{cccc}
\hline & N & Mean & Std. Deviation \\
\hline Economic Issues & 151 & 5.30 & 0.864 \\
Sustainability/Environment Issues & 151 & 5.02 & 0.941 \\
Need of physical space & 151 & 5.75 & 0.954 \\
Imposition of new processes & 151 & 4.48 & 0.908 \\
Matters related to image or reputation & 151 & 4.70 & 0.945 \\
\hline
\end{tabular}

Of the total respondents, $99.3 \%$ had already begun the process of dematerialization. Of these, $87.4 \%(\mathrm{~N}=132)$ started the process between 2010 and 2015, and 21.2\% $(\mathrm{N}=32)$ reported that the process started in 2014. One respondent reported that the process had not started. Fifty-eight point nine percent $(\mathrm{N}=89)$ reported that the process has not ended, and $41.1 \%$ reported the opposite, which is that the process ended already. More specifically, $30.5 \%(N=46)$ of respondents reported that the process ended in 2015 . Sixtyfive point six percent of respondents reported that the time spent on the implementation of dematerialization was between 2 and 4 years $(\mathrm{N}=99)$. The mean was 3.50, and the standard deviation was $2.675(\mathrm{~N}=151)$. The most valued items in terms of motivations for dematerialization (Table 1) were the "need of physical space" (mean: 5.75) and "economic 
issues" (mean: 5.30). The "imposition of new processes" (mean: 4.48) and "matters related to image or reputation" (mean: 4.70) were the items that respondents attributed less importance to in terms of initiating the dematerialization process.

\subsection{Image of Dematerialization}

Table 2 illustrates how "favours the company's image" was the item with a higher mean (mean: 5.32) followed by the item "the process of dematerialization was important" (mean: 5.18). The item "Global Assessment" had a different scale, from "-2 worsened a lot" to "2 improved a lot", so the mean 0.91 and the minimum of 0 (neither worsen nor improved) are good predictors and translate an overall assessment of improvement $(86.1 \%$ of respondents selected " 1 -improved", $N=130$ ). The items with less importance for respondents in terms of image and impact of dematerialization were "sine qua condition to be able to negotiate" (mean: 3.68) and "in no way interferes with the company's image" (mean: 4.30).

Table 2. Image and impact of dematerialization.

\begin{tabular}{|c|c|c|c|}
\hline & $\mathbf{N}$ & Mean & Std. Deviation \\
\hline Favours the company's image & 151 & 5.32 & 0.734 \\
\hline Contributed to a positive image of the company & 151 & 4.95 & 0.893 \\
\hline In no way interferes with the company's image & 151 & 4.30 & 0.980 \\
\hline Sine qua condition to be able to negotiate & 151 & 3.68 & 1.067 \\
\hline Global Assessment ( -2 to 2 dipolar scale) & 151 & 0.91 & 0.364 \\
\hline The process of dematerialization was important & 151 & 5.18 & 0.841 \\
\hline The process of dematerialization contributed to cost reduction & 151 & 4.89 & 0.896 \\
\hline The process of dematerialization contributes to increasing profitability & 151 & 4.94 & 0.889 \\
\hline
\end{tabular}

The item "There are inhibiting factors/blockers for dematerialization" was an open answer type of question. After analysing the $t$ valid answers given by respondents $(\mathrm{N}=139)$, five categories emerged: complexity in procedures, legal demands, resistance to change, compatible technology, and imposition from clients. "Legal demands" was the category chosen by 126 respondents $(90.65 \%)$.

\subsection{Impact of Dematerialization}

For the respondents, the dematerialization had the following consequences:

(a) Seventy-five point five percent $(\mathrm{N}=114)$ estimated a cost reduction of "less than $1 \%$ of the company net sales", while $13.9 \%(\mathrm{~N}=21)$ answered "less than $2.5 \%$ of the company net sales";

(b) Regarding investment in hardware/software, 64.2\% ( $\mathrm{N}=97)$ answered "less than $1 \%$ of the company net sales", and $21.2 \%(\mathrm{~N}=32)$ answered "less than $2.5 \%$ of the company net sales";

(c) Eighty-five point four percent $(\mathrm{N}=129)$ confirmed a reduction in paper consumption (5.54\% on average). The health sector had the higher percentage, $93.3 \%(\mathrm{~N}=14)$, followed by the services sector with $92.6 \%(\mathrm{~N}=25)$ and the industry sector with $90.2 \%$ $(\mathrm{N}=37)$;

(d) The estimated reduction percentage of ESS (External Supplies and Services) spending on paper was $3.16 \%(\mathrm{SD}=6.88 ; \mathrm{N} 127) ; 70.2 \%(\mathrm{~N}=106)$ of the organizations answered less than $2 \%$;

(e) Ninety-five point four percent $(\mathrm{N}=144)$ considered that there were changes in the company/institution's processes;

(f) Concerning legal recognition, 95.4\% $(\mathrm{N}=144)$ thought that the new processes had legal recognition, and $97.3 \%(\mathrm{~N}=147)$ said the processes continue to depend on paper (19.2\% due to the design of internal processes and 78.1\% because of tax/legal motives);

(g) Regarding the dependency on paper, $97.3 \%(\mathrm{~N}=147)$ said the processes continue to depend on paper. From this group, $78.1 \%(\mathrm{~N}=118)$ said the dependency on paper is 
due to tax/legal motives, and $19.2 \%(\mathrm{~N}=29)$ reasoned that it was due to the design of internal processes;

(h) Eighty-four point one percent $(\mathrm{N}=127)$, versus $15.2 \%(\mathrm{~N}=23)$, said that there was no reduction in headcount with the process of dematerialization. Twenty-one organizations mentioned the reduction was until five employees;

(i) Sixty-four point nine percent $(\mathrm{N}=98)$ of respondents referred to the need for the addition of new competencies, while $92.7 \%$ referred to the need for the addition of new training focusing mainly on two areas: Processes $(84.1 \%, \mathrm{~N}=127)$ and IT $(58.9 \%$, $\mathrm{N}=89)$. Twenty-five point two percent $(\mathrm{N}=38)$ took part in training up to $10 \mathrm{~h} /$ year per employee, and $21.9 \%(\mathrm{~N}=33)$ took part in training for more than $20 \mathrm{~h} /$ year per employee;

(j) Moreover, the majority of the sample $(59.6 \%, \mathrm{~N}=90)$ mentioned that there was no promotion of teleworking and/or extension of the work schedule;

(k) Fifty-five point three percent referred that there was no resistance to change;

(l) $96 \%$ of respondents stated that paper is still "an indispensable resource".

\subsection{Hypothesis Debrief}

As the collected data did not have a normal distribution confirmed by the KolmogorovSmirnov and Shapiro-Wilk tests, nonparametric techniques were applied, and the KruskalWallis test [80] was used to study the influence of the sector (postulated by H1). The results suggest that there are significant differences between the activity sector in the following variables:

(1) Higher education, government, and health sectors have a higher average number of employees;

(2) The imposition of new processes occurred more often in the services, trade, and health sectors;

(3) The importance of dematerialization on the impact of image/reputation obtained the maximum score at government $(\mathrm{M}=5.01)$ and the minimum on the industry $(\mathrm{M}=4.32)$;

(4) The reduction in paper consumption was more important for higher education, government, services, and industry. Considering these results, H1 is partially supported; this is in line with Hislop [81] interpretation. These authors affirm that such types of results may affect all economic activities differently.

Significant Spearman correlations coefficients $(R)$ between net sales and importance of dematerialization $(\mathrm{R}=0.237, p=0.000)$, profitability $(\mathrm{R}=0.203, p=0.000)$, and cost reduction $(\mathrm{R}=0.229, p=0.000)$ partially support H2a and H2b. However, there is only a significant correlation between the number of employees and the importance of dematerialization $\left(R^{2}=0.238, p=0.003\right)$. This suggests that companies with more employees may emphasise dematerialization, resulting in more efficient processes [82] and consistent document management [83].

Five factors moderate the different impacts of the dematerialization process: economic issues, sustainability/environmental issues, need of physical space, imposition of new processes by suppliers/customers, and matters related to the image or reputation of the institution towards customers. The results showed that Spearman's correlations are all significant at 0.01 level, suggesting that these five moderators are related positively to each other weakly or moderately ( $\mathrm{R}$ between 0.239 and 0.475 ). Considering these results, H3 is supported. This can be supported by cost reduction [21,63], image benefit [69,70], and space needed for archiving as the number of prints is expected to decrease [43].

Moreover, the Spearman correlation coefficients between the six measures of the consequences of dematerialization are all positive and significant except for the correlation between ESS reduction on paper and the global image improvement. Therefore, hypothesis H4 is partially supported. This is in line with Silveira et al. [84] and Sultoni [85] as the positive outcome of dematerialization benefits consumers and allows companies to improve their image. 
The influence of time (length of dematerialization process) was also analysed. Time has a positive significant weak correlation at 0.01 level with the importance of dematerialization $(R=0.237)$, cost reduction $(R=0.251)$, and paper consumption $(R=0.229)$. There is also a positive significant weak correlation at the 0.05 level with ESS reduction in spending on paper $(R=0.219)$. Global image and perceived profitability increases are not correlated with time. Considering these results, $\mathrm{H} 5$ is partially supported. A positive organizational attitude may increase companies' perceived profitability [86], but there is no evidence that this is timewise connected to any related involvement [87].

\subsection{Predictors of Dematerialization}

Four multiple linear regression models were calculated by using the stepwise methods to complement hypothesis analysis (see Tables 3 and 4 ), aiming to identify the predictors of the contribution of dematerialization for global image, ESS spending on paper, the overall importance of dematerialization, and perceived profitability increase. In this analysis, stepwise regression was used as the standard technique; this technique is used by Arababadi et al. [88] and Noryani et al. [89]. The selection of the variables is based on their level of significance in addition to the advantages of a quick method of automatic selection of the best model that allows the information on the variables to be removed and added, thus, being very useful for analysing the quality of variables predictors.

Table 3. Summary results of multiple linear regression models predicting global image, paper ESS reduction, profitability, and importance of dematerialization.

\begin{tabular}{|c|c|c|c|c|c|c|c|c|c|c|}
\hline \multirow[b]{2}{*}{ Model } & \multirow[b]{2}{*}{$\mathbf{R}$} & \multirow[b]{2}{*}{ R Square } & \multirow{2}{*}{$\begin{array}{l}\text { Adjusted } \\
\text { R Square }\end{array}$} & \multirow{2}{*}{$\begin{array}{l}\text { Std. Error } \\
\text { of the } \\
\text { Estimate }\end{array}$} & \multicolumn{5}{|c|}{ Change Statistics } & \multirow{2}{*}{$\begin{array}{l}\text { Durbin- } \\
\text { Watson }\end{array}$} \\
\hline & & & & & $\begin{array}{l}\text { R Square } \\
\text { Change }\end{array}$ & F Change & df1 & df2 & $\begin{array}{c}\text { Sig. F } \\
\text { Change }\end{array}$ & \\
\hline Global Image & 0.502 & 0.252 & 0.233 & 0.206 & 0.077 & 12.564 & 1 & 122 & 0.001 & 1.796 \\
\hline $\begin{array}{l}\text { Paper ESS } \\
\text { reduction }\end{array}$ & 0.663 & 0.440 & 0.422 & 5.236 & 0.050 & 10.852 & 1 & 121 & 0.001 & 2.062 \\
\hline Profitability & 0.638 & 0.408 & 0.393 & 0.619 & 0.029 & 5.925 & 1 & 122 & 0.016 & 1.870 \\
\hline $\begin{array}{l}\text { Dematerialization } \\
\text { importance }\end{array}$ & 0.847 & 0.717 & 0.705 & 0.407 & 0.020 & 8.573 & 1 & 120 & 0.004 & 1.590 \\
\hline
\end{tabular}

For example, in stepwise multiple linear regressions with the global image as a dependent variable, three predictors were identified to explain the $25 \%$ of the variance of the dependent variable "Global Image" $\left(\mathrm{F}_{3,122}=13,680 ; p<0.001\right)$.

In the first stepwise multiple linear regression, the predictor "matters related to image or reputation of the institution towards customers" has a negative beta coefficient $(-0.349)$, which means that the higher the score in this item, the lower the item "dematerialization contributed to a positive image in the area of sustainability and ecology". The others predictors (dematerialization contributes to profitability increase; contributed to a positive image in the area of sustainability and ecology) have a positive impact on global image.

In the second stepwise multiple linear regression, four predictors were identified to explain $44 \%$ of the variance on the variable "estimated reduction percentage of ESS spending on paper" $\left(\mathrm{F}_{4,121}=23,789 ; p<0.001\right)$. The four predictors identified are the following: need of physical space, reduction in costs, matters related to the image or reputation, and environmental issues. The predictors "need of physical space" and "environmental issues" have a negative beta coefficient ( -0.521 and -0.241 , respectively), which means that the higher the score in these items, the lower the score in the estimated reduction percentage of ESS spending on paper" (see Table 4). The other predictors (reduction in costs and matters related to the image or reputation) have a positive impact in paper ESS reduction (0.314 and 0.279 , respectively). 
Table 4. Beta coefficients of the predictors of the global image, paper ESS reduction, profitability, and importance of dematerialization.

\begin{tabular}{|c|c|c|c|c|c|c|c|c|c|c|c|}
\hline & \multirow{2}{*}{ Model } & \multicolumn{2}{|c|}{$\begin{array}{l}\text { Unstandardized } \\
\text { Coefficients }\end{array}$} & \multirow{2}{*}{$\begin{array}{c}\begin{array}{c}\text { Standardized } \\
\text { Coefficients }\end{array} \\
\text { Beta }\end{array}$} & \multirow[t]{2}{*}{$\mathbf{t}$} & \multirow[t]{2}{*}{ Sig. } & \multicolumn{2}{|c|}{ Correlation } & \multicolumn{3}{|c|}{ Collinearity Statistics } \\
\hline & & B & $\begin{array}{l}\text { Std. } \\
\text { Error }\end{array}$ & & & & $\begin{array}{l}\text { Zero } \\
\text { Order }\end{array}$ & Partial & Part & Tolerance & VIF \\
\hline \multirow{4}{*}{ Global Image } & (Constant) & 0.441 & 0.139 & & 3.164 & 0.002 & & & & & \\
\hline & $\begin{array}{c}\text { Dematerialization } \\
\text { contributes to profitability } \\
\text { increase }\end{array}$ & 0.105 & 0.026 & 0.353 & 4.016 & 0.000 & 0.341 & 0.342 & 0.314 & 0.793 & 1.261 \\
\hline & $\begin{array}{l}\text { Matters related to } \\
\text { reputation }\end{array}$ & -0.086 & 0.022 & -0.349 & -3.964 & 0.000 & -0.096 & -0.338 & -0.310 & 0.789 & 1.267 \\
\hline & $\begin{array}{l}\text { Contributed to a positive } \\
\text { image in the area of } \\
\text { sustainability and ecology }\end{array}$ & 0.085 & 0.024 & 0.313 & 3.545 & 0.001 & 0.313 & 0.306 & 0.278 & 0.786 & 1.272 \\
\hline \multirow{4}{*}{ Paper ESS reduction } & (Constant) & 21.647 & 3.942 & & 5.492 & 0.000 & & & & & \\
\hline & Need of physical space & -3.902 & 0.537 & -0.521 & -7.263 & 0.000 & -0.487 & -0.551 & -0.494 & 0.901 & 1.110 \\
\hline & Reduction in costs & 2.656 & 0.582 & 0.314 & 4.565 & 0.000 & 0.381 & 0.383 & 0.311 & 0.981 & 1.020 \\
\hline & $\begin{array}{l}\text { Matters related to the } \\
\text { image or reputation }\end{array}$ & 2.009 & 0.551 & 0.279 & 3.650 & 0.000 & 0.055 & 0.315 & 0.248 & 0.791 & 1.264 \\
\hline \multirow{4}{*}{ Profitability } & (Constant) & 1.051 & 0.471 & & 2.231 & 0.028 & & & & & \\
\hline & Environmental matters & 0.381 & 0.067 & 0.432 & 5.669 & 0.000 & 0.535 & 0.457 & 0.395 & 0.837 & 1.194 \\
\hline & $\begin{array}{l}\text { Favours the company's } \\
\text { image towards its } \\
\text { customers/competitors }\end{array}$ & 0.345 & 0.092 & 0.291 & 3.762 & 0.000 & 0.487 & 0.322 & 0.262 & 0.814 & 1.229 \\
\hline & Costs reduction & 0.170 & 0.070 & 0.174 & 2.434 & 0.016 & 0.202 & 0.215 & 0.170 & 0.953 & 1.049 \\
\hline \multirow{6}{*}{$\begin{array}{l}\text { Dematerialization } \\
\text { importance }\end{array}$} & (Constant) & -0.419 & 0.382 & & -1.097 & 0.275 & & & & & \\
\hline & Costs reduction & 0.537 & 0.055 & 0.580 & 9.845 & 0.000 & 0.771 & 0.668 & 0.478 & 0.680 & 1.470 \\
\hline & $\begin{array}{l}\text { Favours the company's } \\
\text { image towards its } \\
\text { customers / competitors }\end{array}$ & 0.305 & 0.067 & 0.272 & 4.530 & 0.000 & 0.640 & 0.382 & 0.220 & 0.654 & 1.529 \\
\hline & Economic Issues & 0.148 & 0.052 & 0.144 & 2.824 & 0.006 & 0.344 & 0.250 & 0.137 & 0.902 & 1.109 \\
\hline & Time of dematerialization & 0.047 & 0.016 & 0.147 & 2.976 & 0.004 & 0.088 & 0.262 & 0.145 & 0.960 & 1.041 \\
\hline & $\begin{array}{l}\text { Sine qua non condition } \\
\text { to negotiate }\end{array}$ & 0.104 & 0.036 & 0.147 & 2.928 & 0.004 & 0.227 & 0.258 & 0.142 & 0.933 & 1.072 \\
\hline
\end{tabular}


In the third stepwise multiple linear regression, three predictors were identified to explain $41 \%$ of the variance of the variable "the process of dematerialization contributes to increasing profitability" $\left(\mathrm{F}_{3,122}=27,979 ; p<0.001\right)$. The three predictors identified are the following: environmental matters weighed in the decision; favours the company's image towards its customers/competitors; reduction in costs with the process. All the predictors have a positive impact in the profitability, which means that environmental matters weighed in the decision (0.432), favours the company's image towards its customers/competitors (0.291) and reduction in costs with the process $(0.174)$ contributed positively to increasing profitability.

In the last stepwise multiple linear regression, three predictors were identified to explain $72 \%$ of the variance of the variable "the process of dematerialization was important" $\left(\mathrm{F}_{5,120}=60,811 ; p<0.001\right)$. The five predictors identified are the following: reduction in costs; favours the company's image towards its customers/competitors; economic issues; time of dematerialization; and "it is a sine qua condition to be able to negotiate with some of the suppliers and customers". Table 5 exhibits the summary of the hypotheses results in the present study. These predictors have a positive impact in the dematerialization importance: reduction in costs (0.580); favours the company's image towards its customers/competitors (0.272); economic issues (0.144); time of dematerialization (0.147); and "it is a sine qua condition to be able to negotiate with some of the suppliers and customers" (0.147).

Table 5. Summary of hypotheses results (supported/not supported).

\begin{tabular}{ll}
\multicolumn{1}{c}{ Hypothesis } & \multicolumn{1}{c}{ Confirmation } \\
\hline H1. The type of economic activity sector & \\
influences the benefits and barriers from DPOP & Partially supported \\
measured by indicators. & \\
\hline H2a. Bigger firms (in terms of the number of & \\
employees) have a more favourable evaluation & Partially supported \\
of the impact of the paperless office program. & \\
\hline $\begin{array}{l}\text { H2b. The sales volume is positively correlated } \\
\text { with the indicators measuring the impact of }\end{array}$ & Partially supported \\
paperless office programs. & \\
\hline $\begin{array}{l}\text { H3. There is a positive correlation between the } \\
\text { motivators and the indicators measuring the }\end{array}$ & Supported \\
impact of the paperless office program. & \\
\hline $\begin{array}{l}\text { H4. There are positive correlations between the } \\
\text { indicators measuring the impact of paperless } \\
\text { office program. }\end{array}$ & Partially supported \\
\hline $\begin{array}{l}\text { H5. The length of DPOP is positively } \\
\text { correlated with the indicators. }\end{array}$ & \\
\hline
\end{tabular}

\section{Conclusions}

The evolution from centenary technology based on paper to the latest digital technology that supports documents in dematerialized form compelled both the customers and companies to adapt their modus operandi concerning the manner to produce, communicate, and store documents, which resulted in the Digitization and Paperless Office Program (DPOP). The new technologies are focused on environment and sustainability and were pushed by B2B companies to accomplish new processes to face digital documents. This resulted in positive image impact, profitability increase, cost reduction, and the readiness to negotiate with customers susceptible to sustainable and environmentally friendly technologies.

This paper aims to discuss the consequences of dematerialization through DPOP processes. For more than five centuries, the human brain was formatted for paper usage and since the early days of our lives. With the advent of new technologies, companies 
gradually changed their internal processes from manual paper-based to digital-automated based processes. In addition to ease of use, cost reductions, and environmental friendliness, the main objective of dematerialization is to improve the well-being of society through more efficient and sustainable development [90].

Although paper production and consumption reduction was expected over the years, recent facts prove the contrary case. Between 1991 and 2020, paper and board production increased by $0.9 \%$, and consumption augmented by $0.6 \%$ [39]. On the other hand, due to the strategic nature of the paper pulp production for the Portuguese economy, the total sales of paper pulp was circa 900 Ktonnes in 2008, and this figure increased to 1300 Ktonnes by 2016, out of which 95\% was for export [33]. Moreover, Werner (2015) surprisingly announced a rebound effect on energy consumption. This was supported by the assumption that the reduction in cost of ITC's could inflate energy consumption in the EU due to growing number of installed units. According to Eurostat [59], for the period between 2000 and 2018 , the energy consumed by households in the EU was $605.719,326$ gigawatt-hour in the year 2000 against 705.517, and 655 gigawatt-hour by 2018, which represents an increment of $16.5 \%$ in energy consumption.

Nonetheless, the effects of the DPOP process were observed with positive results amongst B2B companies. Out of the questionnaire sent to a universe of 725 companies in Portugal covering five sectors (education, health, trade, industry, and services), 151 replies were received. The questions aimed to measure the following aspects: global image, reduction in paper expenses, increased profitability, and overall importance of dematerialization. The obtained results show that DPOP processes have positive impacts as they increase the profitability of companies and, in most cases, is a sine qua non condition to negotiate with clients. In addition, it favours the image of companies, reduces costs, and is seen as an important contributor to environmental and sustainability reputations.

From the five formulated hypotheses, four of the following were partially supported: H1. The benefits and barriers from DPOP measured by the indicators are influenced by the type of economic activity sector;

H2a. Bigger firms (in terms of the number of employees) have more favourable evaluation of the impact of paperless office programs;

$\mathrm{H} 2 \mathrm{~b}$. The sales volume is positively correlated with the indicators measuring the impact of paperless office programs;

H4. There are positive correlations between the indicators measuring the impact of the paperless office programs;

H5. The length of DPOP is positively correlated with indicators, and one hypothesis is supported: H3. There is a positive correlation between the motivators and the indicators measuring the impact of the paperless office program.

\subsection{Theoretical and Practical Contributions}

This paper contributes to the theory by filling a literature gap with respect to the consequences of digitization and paperless offices on B2B customers. Moreover, although the expansion of dematerialization is based on the extensive usage of digitization and electronic documents supported by new and efficient technologies, the number of B2B users also increased, causing a greater demand for paper (Jevons Paradox). Regarding practical contributions and managerial implications, the results suggest the following recommendations:

(1) Sector Influence-As the importance of the sector plays a specific role in the process of dematerialization, companies should motivate their internal processes to consider aspects that may facilitate non-material exchange with influential sectors (i.e., distribution sector, find cheaper and efficient dematerialized means to exchange information and documents with legal value). As shown in the discussion of results, the sector influences the importance of the impact on the image, the imposition of new processes, reduce paper consumption, and the importance of dematerialization. We found that this process is being seen with greater strategic importance in the education sector (where the reduction in paper consumption is higher) when com- 
pared with the industry. It follows that the intangible nature of services favours the implementation process.

(2) Image/Marketing: The adoption of dematerialized policies is seen as an eco-friendly behaviour; therefore, companies may positively increase their image when dealing with suppliers and customers. Impact on reputation was a validated area with dematerialization and environmental policies, thus reverting into gains society and companies. As such, this may act as an incentive for companies that have not concluded or are about to conclude their dematerialization processes.

(3) Economic/Financial: Since physical (or archiving) space is a costly area of concern, investment in the correct configuration of document flow to allow immaterial filing and storage may be advisable for future advancement on dematerialization, thus allowing reduction in costs and increasing profitability.

(4) Processes: Simplified and standardized document workflows may be recommended to motivate the adhesion of staff to the DPOP process.

(5) Human Resources (HR): Dematerialization consequences on HR are prone to generating long term investments, resistance to change, downsizing, and necessity for the adequate transition training. Firms should slowly reduce the cognitive aspect of paper usage versus the benefits of dematerialization and promote continuous training to allow all age groups to participate; consequently, this would augment the focus on dematerialization processes.

This being so, we recommend companies to begin the process in order to establish indicators to monitor the reduction in paper consumption and cost reduction, as well as the evolution of the image and reputation with customers because, with the positive evidence of such indicators, it will be easy to continue the implementation of a process that is gradual and time-consuming. Furthermore, taking the opportunity of the dematerialization processes in organizations, we strongly believe that online documents will allow providers to add a variety of complementary services, such as online collaboration tools and online bibliographic services.

\subsection{Limitations and Future Lines of Research}

The present research faced some limitations: (1) although the universe covered 725 companies from five sectors in Portugal, only 151 replies were received, which limited the effective size of the sample; (2) only companies with net sales equal or greater than $10 \mathrm{M} €$ in the year 2014 were used, and this was a strong limitation, as only these types of companies assure the necessary business information. The majority of the companies in Portugal are SME or micro-companies with an annual turnover below $10 \mathrm{M} €$; thus, the contribution to these companies could be questionable. (3) Most of the companies were located in the coastal area of Portugal mainland; as such, inland or islands were not covered. (4) Since the DPOP process covers a new form of disclosure, at this point in time, there is no standardization of KPIs to evaluate and compare metrics amongst organizations.

As for future lines of investigation, this research can serve as a basis for longitudinal studies in the near future. Additionally, it may be used to create new KPIs to be used to measure and benchmark results amongst organizations after the implementation of DPOP. The obtained results could also be used to benchmark other countries of the EU. Moreover, this research may be used to create an agenda to deliver complimentary online services for document transactions, archiving, and recovery. This is important in organizations nowadays, as collaborative and remote working is growing rapidly.

Author Contributions: Conceptualization, J.O., A.A., J.J.F. and J.M.L.; methodology, J.O., A.A. and S.G.; software, J.O. and S.G.; validation, J.O., A.A., J.J.F., J.M.L. and S.G.; formal analysis, J.O., A.A., J.J.F., J.M.L. and S.G.; investigation, J.O., A.A., J.J.F., J.M.L. and S.G.; resources, J.O., A.A., J.J.F., J.M.L. and S.G.; data curation, J.O., A.A. and S.G.; writing-original draft preparation, J.O., A.A., J.J.F., J.M.L. and S.G.; writing - review and editing, J.O., A.A., J.J.F., J.M.L. and S.G.; visualization, J.O., A.A., J.J.F., J.M.L. and S.G.; supervision, J.O. and A.A.; project administration, J.O. and A.A.; funding acquisition, J.J.F. and J.M.L. All authors have read and agreed to the published version of the manuscript. 
Funding: This work is supported by national funds through the FCT-Portuguese Foundation for Science and Technology under the project «UIDB/04630/2020».

Institutional Review Board Statement: The study was conducted according to the guidelines of the Declaration of Helsinki and approved by the Institutional Review Board.

Informed Consent Statement: Informed consent was obtained from all subjects involved in the study.

Data Availability Statement: Data reported in this study can be obtained by contacting the corresponding author.

Conflicts of Interest: The authors declare no conflict of interest.

\section{References}

1. Dacko, S.G.; Claudy, M.; Garcia, R.; Wilner, S.J. Sustainability orientation as a driver of innovation within firms. In Proceedings of the ISPIM Conference Proceedings, Helsinki, Finland, 16-19 June 2013; p. 1.

2. Battaglia, M.; Annesi, N.; Calabrese, M.; Frey, M. Do agenda 2030 and Sustainable Development Goals act at local and operational levels? Evidence from a case study in a large energy company in Italy. Bus. Strateg. Dev. 2020, 3, 603-614. [CrossRef]

3. Coreynen, W.; Matthyssens, P.; Van Bockhaven, W. Boosting servitization through digitization: Pathways and dynamic resource configurations for manufacturers. Ind. Mark. Manag. 2017, 60, 42-53. [CrossRef]

4. Tronvoll, B.; Sklyar, A.; Sorhammar, D.; Kowalkowski, C. Transformational shifts through digital servitization. Ind. Mark. Manag. 2020, 89, 293-305. [CrossRef]

5. Venkatesh, V.; Thong, J.Y.; Xu, X. Consumer acceptance and use of information technology: Extending the unified theory of acceptance and use of technology. MIS Q. 2012, 36, 157-178. [CrossRef]

6. Ayres, R.U.; van den Bergh, J.C.J.M. A theory of economic growth with material/energy resources and dematerialization: Interaction of three growth mechanisms. Ecol. Econ. 2005, 55, 96-118. [CrossRef]

7. Kowalkowski, C.; Gebauer, H.; Kamp, B.; Parry, G. Servitization and deservitization: Overview, concepts, and definitions. Ind. Mark. Manag. 2017, 60, 4-10. [CrossRef]

8. Chao, C. Implementing a Paperless System for Small and Medium-Sized Businesses (SMBs). Master's Thesis, University of Oregon, Eugene, OR, USA, 2016.

9. Caldeira, M.; Serrano, A.; Quaresma, R.; Pedron, C.; Romão, M. Information and communication technology adoption for business benefits: A case analysis of an integrated paperless system. Int. J. Inf. Manag. 2012, 32, 196-202. [CrossRef]

10. Pothen, F.; Schymura, M. Bigger cakes with fewer ingredients? A comparison of material use of the world economy. Ecol. Econ. 2015, 109, 109-121. [CrossRef]

11. Taylor, C.D.; Gully, B.; Sánchez, A.N.; Rode, E.; Agarwal, A.S. Towards Materials Sustainability through Materials Stewardship. Sustainability 2016, 8, 1001. [CrossRef]

12. Bais, A.L.S.; Lauk, C.; Kastner, T.; Erb, K. Global patterns and trends of wood harvest and use between 1990 and 2010. Ecol. Econ. 2015, 119, 326-337. [CrossRef]

13. Gnoni, M.G.; Elia, V. An environmental sustainability analysis in the printing sector. Int. J. Sustain. Eng. 2013, 6, 188-197. [CrossRef]

14. Yoo, Y.; Henfridsson, O.; Lyytinen, K. Research commentary-the new organizing logic of digital innovation: An agenda for information systems research. Inf. Syst. Res. 2010, 21, 724-735. [CrossRef]

15. Hylving, L.; Schultze, U. Accomplishing the layered modular architecture in digital innovation: The case of the car's driver information module. J. Strateg. Inf. Syst. 2020, 29, 101621. [CrossRef]

16. Sotnyk, I.; Zavrazhnyi, K.; Kasianenko, V.; Roubík, H.; Sidorov, O. Investment Management of Business Digital Innovations. Mark. Manag. Innov. 2020, 1, 95-109. [CrossRef]

17. Roubtsova, E.; Michell, V. Modelling and validation of KPIs. In Proceedings of the BMSD 2013-The 3rd International Symposium on Business Modeling and Software Design, Noordwijkerhout, The Netherlands, 8-10 July 2013; pp. 96-105.

18. Zarzycka, E.; Krasodomska, J. Non-financial key performance indicators: What determines the differences in the quality and quantity of the disclosures? J. Appl. Account. Res. 2021, 1-24, ahead of print. [CrossRef]

19. EC. Guidelines on Non-Financial Reporting; European Commission (EC): Brussels, Belgium, 2017; p. 20.

20. Varadarajan, R. Innovating for sustainability: A framework for sustainable innovations and a model of sustainable innovations orientation. J. Acad. Mark. Sci. 2017, 45, 14-36. [CrossRef]

21. Gardenal, F. A model to measure e-procurement impacts on organizational performance. J. Public Procure. 2013, 13, 215-242. [CrossRef]

22. Digilina, O.B.; Teslenko, I.B.; Abdullaev, N.V. Industry 4.0: Contents, Problems and Perspectives. In Perspectives on the Use of New Information and Communication Technology; Popkova, E.G., Ostrovskaya, V.N., Eds.; Advances in Intelligent Systems and Computing; Springer: Berlin/Heidelberg, Germany, 2019; Volume 726, pp. 32-38.

23. Gallego, T.; Collado, M.L.; Tolosa, L. Updating students digital skills according to professional needs. In Proceedings of the 14th International Technology, Education and Development Conference, Valencia, Spain, 2-4 March 2020; Chova, L.G., Martinez, A.L., Torres, I.C., Eds.; IATED: Valencia, Spain, 2020; pp. 6391-6398. 
24. Shin, S.C.; Rakhmatullayev, Z.M. Digital Transformation of the Public Service Delivery System in Uzbekistan. In Proceedings of the 2019 21st International Conference on Advanced Communication Technology, PyeongChang, Korea, 17-20 February 2019; pp. 703-709.

25. Gebauer, H.; Ren, G.J.; Valtakoski, A.; Reynoso, J. Service-driven manufacturing. J. Serv. Manag. 2012, 23, 120-136. [CrossRef]

26. Malenbaum, W. World Demand for Raw Materials in 1985 and 2000; McGraw-Hill: New York, NY, USA, 1978.

27. Bernardini, O.; Galli, R. Dematerialization: Long-term trends in the intensity of use of materials and energy. Futures 1993, 25, 431-448. [CrossRef]

28. Schandl, H.; Hatfield-Dodds, S.; Wiedmann, T.; Geschke, A.; Cai, Y.; West, J.; Newth, D.; Baynes, T.; Lenzen, M.; Owen, A. Decoupling global environmental pressure and economic growth: Scenarios for energy use, materials use and carbon emissions. J. Clean. Prod. 2016, 132, 45-56. [CrossRef]

29. Lawson, C.; Rourke, M.; Humphries, F. Information as the latest site of conflict in the ongoing contests about access to and sharing the benefits from exploiting genetic resources. Queen Mary J. Intellect. Prop. 2020, 10, 7-33. [CrossRef]

30. Dietzenbacher, E.; Los, B.; Stehrer, R.; Timmer, M.; de Vries, G. The Construction of World Input-Output Tables in the Wiod Project. Econ. Syst. Res. 2013, 25, 71-98. [CrossRef]

31. Di Berardino, C.; Onesti, G. Explaining deindustrialisation from a vertical perspective: Industrial linkages, producer services, and international trade. Econ. Innov. New Technol. 2020, 1-22. [CrossRef]

32. Jiborn, M.; Kulionis, V.; Kander, A. Consumption versus Technology: Drivers of Global Carbon Emissions 2000-2014. Energies 2020, 13, 339. [CrossRef]

33. CELPA. Electricity and Heat Statistics; Associação da indústria Papeleira: Lisboa, Portugal, 2020; p. 92.

34. Magee, C.L.; Devezas, T.C. A simple extension of dematerialization theory: Incorporation of technical progress and the rebound effect. Technol. Forecast. Soc. Chang. 2017, 117, 196-205. [CrossRef]

35. Siami, N.; Winter, R.A. Jevons' paradox revisited: Implications for climate change. Econ. Lett. 2021, 206, 109955. [CrossRef]

36. Davidson, D.J.; Andrews, J.; Pauly, D. The effort factor: Evaluating the increasing marginal impact of resource extraction over time. Glob. Environ. Chang. 2014, 25, 63-68. [CrossRef]

37. York, R. Ecological Paradoxes: William Stanley Jevons and the Paperless Office. Hum. Ecol. Rev. 2006, 13, $143-147$.

38. RISI. Fastmarkets RISI-The Definitive Source of Forest Products PRICE Data and Market Intelligence. Available online: https: / / www.risiinfo.com/ (accessed on 17 June 2021).

39. CEPI. European Pulp E Paper Industry; Confederation of European Paper Industries: Brussels, Belgium, 2020.

40. Greenwood, P. Securing information in a paper-efficient environment. Comput. Fraud Secur. 2012, 2012, 18-20. [CrossRef]

41. Cumming, K.; Findlay, C. Digital recordkeeping: Are we at a tipping point? Rec. Manag. J. 2010, 20, 265-278. [CrossRef]

42. Ali, S.M.; Naureen, F.; Noor, A.; Boulos, M.N.K.; Aamir, J.; Ishaq, M.; Anjum, N.; Ainsworth, J.; Rashid, A.; Majidulla, A.; et al. Data Quality: A Negotiator between Paper-Based and Digital Records in Pakistan's TB Control Program. Data $2018,3,27$. [CrossRef]

43. Jones, S. eGovernment Document Management System: A case analysis of risk and reward. Int. J. Inf. Manag. 2012, 32, 396-400. [CrossRef]

44. Declich, A.; Quinti, G.; Signore, P. SME's, energy efficiency, innovation: A reflection on materials and energy transition emerging from a research on SMEs and the practice of Energy Audit. Mater. Tech. 2021, 108, 505. [CrossRef]

45. Murrell, M. Out of Print: The Orphans of Mass Digitization. Curr. Anthropol. 2017, 58, S149-S159. [CrossRef]

46. Jabr, F. Why the Brain Prefers Paper. Sci. Am. 2013, 309, 48-53. [CrossRef] [PubMed]

47. Vandermerwe, S.; Rada, J. Servitization of business: Adding value by adding services. Eur. Manag. J. 1988, 6, 314-324. [CrossRef]

48. Brax, S.A.; Visintin, F. Meta-model of servitization: The integrative profiling approach. Ind. Mark. Manag. 2017, 60, 17-32. [CrossRef]

49. Baines, T.S.; Lightfoot, H.W.; Benedettini, O.; Kay, J.M. The servitization of manufacturing. J. Manuf. Technol. Manag. 2009, 20, 547-567. [CrossRef]

50. Hallstedt, S.I.; Isaksson, O.; Ronnback, A.O. The Need for New Product Development Capabilities from Digitalization, Sustainability, and Servitization Trends. Sustainability 2020, 12, 222. [CrossRef]

51. Sholihah, M.; Maezono, T.; Mitake, Y.; Shimomura, Y. Formulating Service-Oriented Strategies for Servitization of Manufacturing Companies. Sustainability 2020, 12, 9657. [CrossRef]

52. Xu, Q.; Yu, J.H.; Xu, J.X.; Zhang, G.X.; Liang, C.Y. How business model innovation overcomes barriers during manufacturers' servitization transformation: A case study of two top piano manufacturers in China. Asia Pac. Bus. Rev. 2021, 27, 378-404. [CrossRef]

53. Bustinza, O.F.; Gomes, E.; Vendrell-Herrero, F.; Baines, T. Product-service innovation and performance: The role of collaborative partnerships and R\&D intensity. RD Manag. 2019, 49, 33-45. [CrossRef]

54. Oliva, R.; Kallenberg, R. Managing the transition from products to services. Int. J. Serv. Ind. Manag. 2003, 14, 160-172. [CrossRef]

55. Kohtamäki, M.; Helo, P. Industrial services-The solution provider's stairway to heaven or highway to hell? Benchmarking Int. J. 2015, 22, 170-185. [CrossRef]

56. Visintin, F. Providing integrated solutions in the professional printing industry: The case of Océ. Comput. Ind. 2012, 63, 379-388. [CrossRef]

57. Infosource. Information That Empowers. Available online: https:/ /www.info-source.com/ (accessed on 17 June 2021). 
58. Werner, P. The Rebound Effect of Information and Communication Technologies Development in the European Union. Appl. Spat. Anal. Policy 2015, 8, 409-423. [CrossRef]

59. Eurostat. Electricity and HEAT Statistics. Available online: https://ec.europa.eu/eurostat/statistics-explained/index.php?title= Electricity_and_heat_statistics\#Consumption_of_electricity_and_derived_heat (accessed on 17 June 2021).

60. Boe, R.J.; Kennedy, J.; Coyne, J.S.; Smith, G.J. Implementation of Paperless Credentialing in a Multi-State Managed Care Organization. Am. J. Manag. Care 2012, 18, E31-E34.

61. Chowdhury, G. Carbon footprint of the knowledge sector: What's the future? J. Doc. 2010, 66, 934-946. [CrossRef]

62. Gibson, C.C.; Ostrom, E.; Ahn, T.K. The concept of scale and the human dimensions of global change: A survey. Ecol. Econ. 2000, 32, 217-239. [CrossRef]

63. Davis, J.T.; Hadley, J.; Davis, H. Paperless processes: Survey of CPA firms in a smaller market regarding obstacles, challenges and benefits of implementation. Int. J. Acad. Bus. World 2015, 9, 49-59.

64. Holmlund, M.; Kowalkowski, C.; Biggemann, S. Organizational behavior in innovation, marketing, and purchasing in business service contexts-An agenda for academic inquiry. J. Bus. Res. 2016, 69, 2457-2462. [CrossRef]

65. Windahl, C.; Lakemond, N. Integrated solutions from a service-centered perspective: Applicability and limitations in the capital goods industry. Ind. Mark. Manag. 2010, 39, 1278-1290. [CrossRef]

66. Gray, E.R.; Balmer, J.M.T. Managing Corporate Image and Corporate Reputation. Long Range Plan. 1998, 31, 695-702. [CrossRef]

67. Velte, T.; Velte, A.; Elsenpeter, R. Green-IT: Reduce Your Information System's Environmental Impact While Adding to the Bottom Line. 2008; McGraw-Hill: New York, NY, USA, 2008.

68. Davis, J.T.; Davis, H.T. Less is more-paper and profitability. J. Account. Financ. Res. 2004, 12, 33-38.

69. Dorota, B.-O. Corporate Social Responsibility as Part of Company Image Management in Banking Institutions. Acta Sci. Polonorum. Oeconomia 2016, 15, 5-14.

70. Meena, R. Green banking: As initiative for sustainable development. Glob. J. Manag. Bus. Stud. 2013, 3, 1181-1186.

71. Coroama, V.C.; Schien, D.; Preist, C.; Hilty, L.M. The Energy Intensity of the Internet: Home and Access Networks. In ICT Innovations for Sustainability; Springer: Cham, The Netherlands, 2015; pp. 137-155.

72. Stratton, A. Pursuing the possibility of a paperless office. Inf. Manag. 2013, 47, 44.

73. Alves, R.; Caneiras, C.; Santos, A.I.; Barbosa, P.; Cardoso, J.; Caseiro, P.; Vitorino, M.J.; Pereira, J.; Escoval, A. Medical Electronic Prescription for Home Respiratory Care Services (PEM-CRD) at a Portuguese University Tertiary Care Centre (2014-2018): A Case Study. Sustainability 2020, 12, 9859. [CrossRef]

74. Carvalho, J.V.; Pereira, R.H.; Rocha, A. A Comparative Study on Maturity Models for Information Systems in Higher Education Institutions. In Digital Science; Antipova, T., Rocha, A., Eds.; Advances in Intelligent Systems and Computing; Springer: Cham, The Netherlands, 2019; Volume 850, pp. 150-158.

75. Hadad, S.; Bratianu, C. Dematerialization of banking products and services in the digital era. Manag. Mark. Chall. Knowl. Soc. 2019, 14, 318-337. [CrossRef]

76. Wang, Y.; Zeng, D.; Di Benedetto, C.A.; Song, M. Environmental determinants of responsive and proactive market orientations. J. Bus. Ind. Mark. 2013, 28, 565-576. [CrossRef]

77. Arinze, B.; Anandarajan, M. Factors that determine the adoption of cloud computing: A global perspective. Int. J. Enterp. Inf. Syst. (IJEIS) 2010, 6, 55-68. [CrossRef]

78. Hair, J.F.; Risher, J.J.; Sarstedt, M.; Ringle, C.M. When to use and how to report the results of PLS-SEM. Eur. Bus. Rev. 2019, 31, 2-24. [CrossRef]

79. Vendrell-Herrero, F.; Bustinza, O.F.; Parry, G.; Georgantzis, N. Servitization, digitization and supply chain interdependency. Ind. Mark. Manag. 2017, 60, 69-81. [CrossRef]

80. Ostertagová, E.; Ostertag, O.; Kováč, J. Methodology and Application of the Kruskal-Wallis Test. Appl. Mech. Mater. 2014, 611, 115-120. [CrossRef]

81. Hislop, H. Reinventing the Wheel: A Circular Economy for Resource Security; Green Alliance: London, UK, 2011.

82. Astola, P.J.; Rodríguez, P.; Botana, J.; Marcos, M. A paperless based methodology for managing Quality Control. Application to a I+D+i Supplier Company. Procedia Manuf. 2017, 13, 1066-1073. [CrossRef]

83. Ivanov, D.; Dolgui, A.; Sokolov, B. The impact of digital technology and Industry 4.0 on the ripple effect and supply chain risk analytics. Int. J. Prod. Res. 2019, 57, 829-846. [CrossRef]

84. Silveira, P.D.; Galvão, S.; Bogas, P. The influence of customer retention time on slogan recall and recognition: An empirical study. Int. J. Econ. Bus. Adm. 2018, 6, 3-13.

85. Sultoni, M.H. The Influence of Corporate Social Responsibility Programs To The Image of Corporations. AFEBI Manag. Bus. Rev. 2016, 1, 1-11. [CrossRef]

86. Cressman, G.E. Value-based Pricing: A State-of-the-Art Review. In Handbook of Business-to-Business Marketing; Lilien, G., Grewal, R., Eds.; Edward Elgar Publishing: Northampton, MA, USA, 2012; p. 29.

87. Sit, J.K.; Hoang, A.; Inversini, A. Showrooming and retail opportunities: A qualitative investigation via a consumer-experience lens. J. Retail. Consum. Serv. 2018, 40, 163-174. [CrossRef]

88. Arababadi, R.; Naganathan, H.; Saffari Pour, M.; Dadvar, A.; Parrish, K.; Chong, O. Building stock energy modeling: Feasibility study on selection of important input parameters using stepwise regression. Energy Sci. Eng. 2021, 9, 284-296. [CrossRef] 
89. Noryani, M.; Sapuan, S.M.; Mastura, M.T.; Zuhri, M.Y.M.; Zainudin, E.S. Material selection of natural fibre using a stepwise regression model with error analysis. J. Mater. Res. Technol. 2019, 8, 2865-2879. [CrossRef]

90. Kestemont, B.; Kerkhove, M. Material flow accounting of an Indian village. Biomass Bioenergy 2010, 34, 1175-1182. [CrossRef] 